\title{
PENERAPAN C 4.5 UNTUK MENENTUKAN CALON SUAMI TERBAIK DALAM PERNIKAHAN PADA KANTOR KUA SIANTAR MARTOBA PEMATANGSIANTAR
}

\author{
Siti Hawani', Dedy Hartama ${ }^{2}$, Agus Perdana Windarto ${ }^{3}$, Solikun ${ }^{4}$ \\ ${ }^{1}$ Mahasiswa Program Studi S-1 Sistem Informasi, STIKOM Tunas Bangsa Pematangsiantar, Indonesia \\ Jalan Sudirman Blok A No. 1, 2, 3 Kota Pematangsiantar \\ ${ }^{2,3,4}$ Program Studi S-1 Sistem Informasi, STIKOM Tunas Bangsa Pematangsiantar, Indonesia \\ Jalan Sudirman Blok A No. 1, 2, 3 Kota Pematangsiantar \\ E-mail : siti.hawani24@gmail.com¹ dedyhartama@amiktunasbangsa.ac.id ${ }^{2}$ \\ zhantura.gusti@gmail.com³ solikun@amiktunasbangsa.ac.id ${ }^{4}$
}

\begin{abstract}
Abstrak
Penentuan Calon Suami terbaik merupakan salah satu cara untuk mengetahui kriteriakriteria apa yang diperlukan dalam penentuan calon suami terbaik dalam pernikahan .Seorang calon suami harus memenuhi beberapa kriteria tertentu untuk dapat dinyatakan layak. Penelitihan ini bertujuan untuk mengklasifikasikan dan memprediksi layak dan tidak layak calon suami untuk dinyatakan menjadi calon suami terbaik dalam pernikahan dengan menggunakan Metode C4.5. Algoritma C4.5 merupakan algoritma yang digunakan untuk membentuk pohon keputusan. Pohon keputusan merupakan metode klasifikasi dan prediksi yang sangat kuat dan terkenal.
\end{abstract}

Kata kunci : Calon suami; klasifikas; algoritma C4.5

\section{Pendahuluan}

Calon suami adalah calon pengatin pria dalam sebuah pernikahan yang mempunyai tanggung jawab penuh dalam membangun rumah tangga. Suami mempunyai peranan penting, bukan hanya mencari nafkah akan tetapi suami sebagai motivator dalam berbagai kebijakan yang akan di putuskan termasuk merencanakan keluarga. Menurut Humas Badan Koordinasi Keluarga Berencana Nasional (BKKBN), usia wanita menikah minimal 20 tahun dan Pria 25 tahun. Dikarenakan pernikahan yang dilakukan diusia cukup muda antara 12 hingga 21 tahun, 3 kali lebih banyak berakhir dengan perceraian di bandingkan pernikahan pada usia yang lebih matang. Contohnya pada KUA Siantar Martoba Pematansiantar masih ada calon suami yang tidak sesuai dengan kriteria.

Di dalam sebuah Pernikahan Calon Suami mempunyai peranan yang sangat penting. Calon Suami harus memiliki kriteria khusus. Calon suami dituntut bertanggung jawab terhadap istri dalam hal menafkahi maupun mengambil keputusan yang bijak dalam merencanakan keluarga. Untuk meraih rumah tangga yang baik dipengaruhi oleh kematangan baik secara umur maupun pekerjaan. Penentuan calon suami terbaik merupakan salah satu cara meningkatkan kesadaran pria akan pentingnya kesiapan mental dan finansial dalam pernikahan. Untuk menentukan kriteriacalon suami dalam pernikahan di KUA Siantar Martoba Pematangsiantar. Penilaian Umur dan pekerjaan Calon suami sangat penting 
dalam menentukan calon suami yang terbaik dalam pernikahan.

Untuk mengklasifikasi dan memprediksi calon suami digunakan Metode C 4.5. Menurut jurnal (Anik Andriani, Penerapan Algoritma C4.5 Pada Program Klasifikasi Mahasiswa Dropout, 2012)[1] Algoritma C4.5 merupakan algoritma yang digunakan untuk membentuk pohon keputusan. Pohon keputusan merupakan metode klasifikasi dan prediksi yang sangat kuat dan terkenal. Metode pohon keputusan mengubah fakta yang sangat besar menjadi pohon keputusan yang merepresentasikan aturan. Aturan dapat dengan mudah dipahami dengan bahasa alami. Dan mereka juga dapat diekspresikan dalam bentuk bahasa basis data seperti Structured Query Language untuk mencari record pada kategori tertentu.

Tujuan dari penelitian ini untuk mengetahui proses penentuan calon suami terbaik dalam pernikahan pada Kantor KUA Siantar Martoba Pematangsiantar, mengetahui kriteriakriteria apa yang diperlukan dalam penentuan calon suami terbaik dalam pernikahan, menerapkan metode $\mathrm{C} 4.5$ dalam proses penentuan calon suami terbaik dalam pernikahan, dan penentuan calon suami terbaik dalam pernikahan pada Kantor KUA Siantar Martoba Pematangsiantar.

\section{Metode Penelitian}

Data Mining adalah suatu istilah yang diguna- kan untuk menguraikan penemuan pengetahuan di dalam database (Sukma, 2015)[2]. Algoritma C4.5 merupakan algoritma yang digunakan untuk membentuk pohon keputusan. Sedang pohon keputusan dapat diartikan suatu cara untuk memprediksi atau mengklarifikasi yang sangat kuat. Pohon keputusan merupakan metode klasifikasi dan prediksi yang sangant kuat dan terkenal.

\section{Hasil dan Pembahasan}

Metode pohon kepusan mengubah fakta yang sangat besar menjadi pohon keputusan yang mempresentasikan aturan.

Tabel 1. Keputusan bermain tenis

\begin{tabular}{|c|c|c|c|c|}
\hline OUTLOOK & TEMPE & HUMIDIT & WI & PL \\
\hline Sunny & Hot & High & FA & No \\
\hline Sunny & Hot & High & TR & No \\
\hline Cloudy & Hot & High & FA & Yes \\
\hline Rainy & Mild & High & FA & Yes \\
\hline Rainy & Cool & Normal & FA & Yes \\
\hline Rainy & Cool & Normal & TR & Yes \\
\hline Cloudy & Cool & Normal & TR & Yes \\
\hline Sunny & Mild & High & FA & No \\
\hline Sunny & Cool & Normal & FA & Yes \\
\hline Rainy & Mild & Normal & FA & Yes \\
\hline Sunny & Mild & Normal & TR & Yes \\
\hline Cloudy & Mild & High & TR & Yes \\
\hline Cloudy & Hot & Normal & FA & Yes \\
\hline Rainy & Mild & High & TR & No \\
\hline
\end{tabular}

pada tabel 1 akan dibuat pohon keputusan untuk menentukan main tennis atau tidak dengan melihat keadaan cuaca, temperatur, kelembaban, dan keadaan angin.

Secara umum algopritma C4.5 untuk membangun pohon keputusan adalah sebagai berikut.

a. Pilih Atribut sebgai akar.

b. Baut cabang untuk tiap-tiap nilai.

c. Bagi kasus dalam canbang.

d. Ulangi proses untuk setiap cabang sampai semua kasus pada cabang memiliki kelas yang sama. Untuk memilih atribut sebagai akar, didasarkan pada nilai gain tertinggi dari atribut-atribut yang ada. Untuk menghitung gain digunakan ,rumus seperti pada persamaan berikut.

$\operatorname{Gaint}(S, A)=\operatorname{Entropy}(S) \sum_{i=l}^{n} \frac{\left|\mathrm{S}_{\mathrm{i}}\right|}{|\mathrm{S}|} *$ 


\author{
Keterangan : \\ S : Himpunan kasus \\ A : Atribut \\ n : Jumlah Partisi Atribut A \\ |Si| : Jumlah kasus pada partisi ke-i \\ $|\mathrm{S}| \quad$ : Jumlah Kasus dalam S \\ Sementara itu, penghitungan \\ nilai entropi dapat dilihat pada \\ persamaan berikut.
}

\section{$\log _{2} p i$}

Keterangan :

$\begin{array}{ll}\mathrm{S} & \text { : Himpunan kasus } \\ \mathrm{A} & \text { : Fitur } \\ \mathrm{n} & \text { : Jumlah partisi S } \\ \text { pi } & \text { : Proporsi dari Si terhadap S }\end{array}$

Algoritma C4.5 merupakan algoritma yang digunakan untuk membentuk pohon keputusan. Sedang pohon keputusan dapat diartikan suatu cara untuk memprediksi atau mengklarifikasi yang sangat kuat. Preprocessing Data merupakan salah satu langkah yang digunakan untuk validasi sebuah data yang akan di jakan objek pengujian. Di dalam preprocessing salah satu langkah yang digunakan adalah transformasi setiap nilai attribut yang sama ke bentuk numerik sehingga mudah dilakukan untuk proses pemecahan masalah dan pembentukan data sampelnya. Berikut ini adalah pre-processing data ujinya.

1. Pekerjaan Calon Suami

Untuk Pekerjaan Calon Suami diklasifikasikan menjadi 2(dua) jenis yaitu:

a. Bernilai 4 apabila "Statusnya" = TNI/PNS/Karyawan BUMN

b. Bernilai 3 apabila "Statusnya" = Wiraswasta/Wirausaha/Petani

c. Bernilai 2 apabila "Statusnya" = Karyawan Swasta

d. Bernilai 1 apabila "Statusnya" = BHL/Bangunan

e. Bernilai 0 apabila "Statusnya" = Belum Bekerja
2. Usia calon suami

Untuk Usia Calon Suami

diklasifikasikan menjadi 2(dua)

jenis yaitu:

a. Bernilai 1 apabila "Umur" $=">=25$ "

b. Bernilai 0 apabila "Umur" = " $<25$ "

Gaint $(S, A)=\operatorname{Entropy}(S) \sum_{i=l}^{n}$

3. Penilaian KUA yaitu kelengkapan berkas untuk penilaian siswa diklasifikasikan menjadi 3 (tiga) jenis yaitu:

a. Bernilai 1 apabila "Kurang"

b. Bernilai 2 apabila "Baik"

c. Bernilai 3 apabila "Sangat Baik"

Tabel 2. Data decision penilaian guru

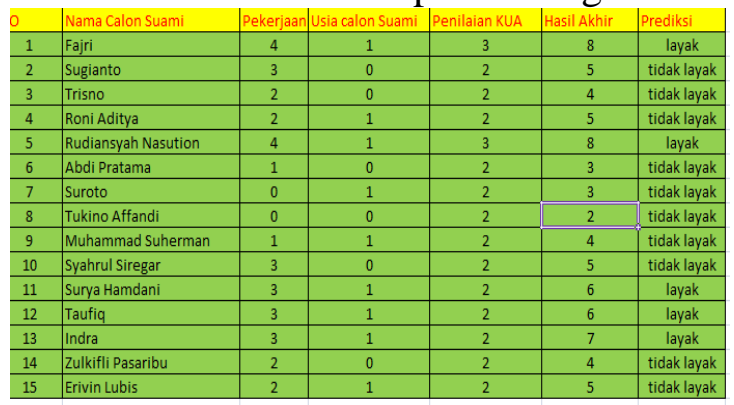

Pilih Atribut Akar

Untuk memilih atribut sebagai akar, didasarkan pada nilai Gain tertinggi dari atribut-atribut yang ada sedangkan untuk menghitung nilai entropy dapat dilihat pada rumus menggunakan dua persamaan di atas maka akan didapatkan entropy dan gain yang digunakan sebagai akar dalam membuat pohon keputusan.

a. Entropy Total

Untuk menghitung Nilai Entropy

Berdasarkan penilaian keseluruhan

Calon suami berdasarkan tabel Data

Decision Penilaian Calon Suami

Diketahui:

Nilai Objek Keseluruhan $(\mathrm{Si})=15$

Nilai Atribut Hasil $($ Layak $)=5$

Nilai Atribut Hasil (Tidak Layak) = 
10

Maka:

Entropy Total $=\left(-5 / 15^{*} \log \right.$

$2(5 / 15))+(-10 / 15 * \log 2(10 / 15)$

$=0.721928095$

Maka berikut ini adalah nilai rekapitulasi Entropy- nya:

Tabel 3. Hasil perhitungan entropy

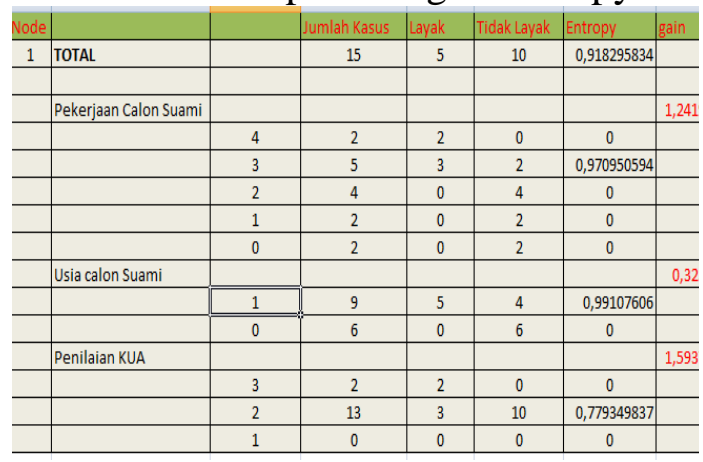

Tabel 4. Perangkingan berdasarkan nilai gain

\begin{tabular}{c|l|c|c} 
No & \multicolumn{1}{|c|}{ Kriteria } & Nilai Gain & Peringkat \\
\hline 1 & Penilaian KUA & 1,59373236 & 1 \\
\hline 2 & Pekerjaan Calon Suami & 1,241946032 & 2 \\
\hline 3 & Usia calon Suami & 0,323650198 & 3 \\
\hline
\end{tabular}

Tabel 5. Hasil pohon keputusan 1.0

\begin{tabular}{c|c|c|c|c|c|c|c}
\hline Node & & & Jumlah Kasus & Layak & Tidak Layak & Entropy & gain \\
\hline 1.0 & Penilaian KUA & & & & & & 1,5937 \\
\hline & & 3 & 2 & 2 & 0 & 0 & \\
\hline & & 2 & 13 & 3 & 10 & 0,7793498 & \\
\hline & & 1 & 0 & 0 & 0 & 0 & \\
\hline
\end{tabular}

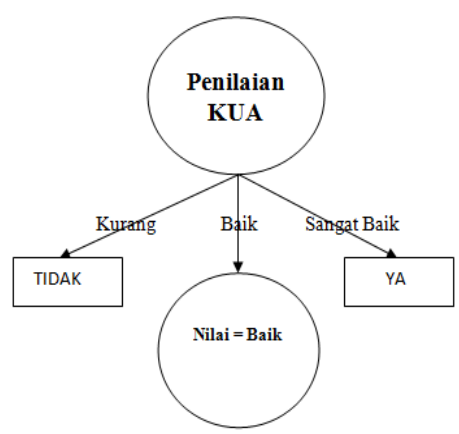

Gambar 1. Pohon keputusan
Tabel 6. Nilai entropy gain lanjutan

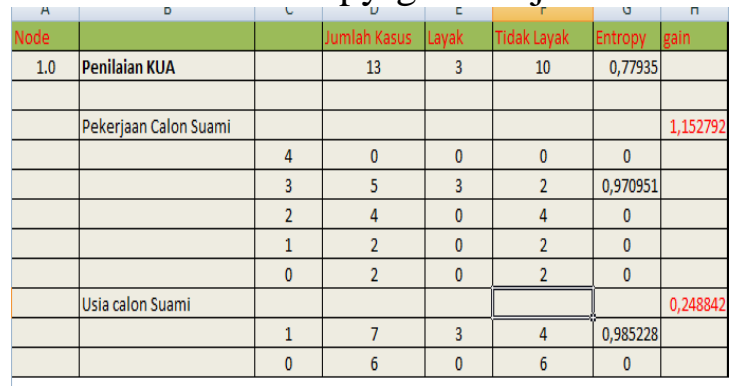

b. Kandidat yang prioritas (layak) untuk menjadi Guru Terbaik

Data kandidat yang menjadi prioritas dilihat berdasarkan prioritas dan pohon keputusan yang tergambar pada gambar1Pohon keputusan. Berikut ini adalah rekapitulasi dari hasil peniliannya. Prioritas 1 adalah Kandidat yang memiliki nilai 3 . Tabel 7. Prioritas 1

\begin{tabular}{c|l|c|c}
\hline \multicolumn{1}{l|}{ NO } & Nama Calon Suami & Penilaian KUA & Prediksi \\
\hline 1 & Fajri & 3 & layak \\
\hline 2 & Rudiansyah Nasution & 3 & layak \\
\hline
\end{tabular}

Tabel 8. Prioritas 2

\begin{tabular}{c|l|c|c}
\hline NO & Nama Calon Suami & Penilaian KUA & Prediksi \\
\hline 1 & Sugianto & 2 & tidak layak \\
\hline 2 & Trisno & 2 & tidak layak \\
\hline 3 & Roni Aditya & 2 & tidak layak \\
\hline 4 & Abdi Pratama & 2 & tidak layak \\
\hline 5 & Suroto & 2 & tidak layak \\
\hline 6 & Tukino Affandi & 2 & tidak layak \\
\hline 7 & Muhammad Suherman & 2 & tidak layak \\
\hline 8 & Syahrul Siregar & 2 & tidak layak \\
\hline 9 & Surya Hamdani & 2 & layak \\
\hline 10 & Taufiq & 2 & layak \\
\hline 11 & Indra & 2 & tidak layak \\
\hline 12 & Zulkifli Pasaribu & 2 & tidak layak \\
\hline 13 & Erivin Lubis & & \\
& &
\end{tabular}

\section{Kesimpulan}

Proses penentuan calon suami terbaik dalam pernikahan pada KUA Siantar Martoba Pematangsiantar dan penggunaan algoritma C4.5 sebagai solusi pemecahan masalah dapat di jadikan sebagai rujukan. Kriteriakriteria yang digunakan dalam penentuan calon suami terbaik dalam pernikahan pada KUA Siantar Martoba Pematangsiantar sangat relevan dan tepat sekali karena menggunakan 
beberapa unsur tidak hanya penilian secara usia, pekerjaan tetapi juga penilaian KUA.

\section{Daftar Pustaka}

[1] Anik Andriani, "Jurnal Penerapan Algoritma C4.5 Pada Program Klasifikasi Mahasiswa Dropout", 2012)

[2] Sukma Putri Utari, (2015).

"Implementasi Metode C4.5 Untruk Menentukan Guru Terbaik pada SMK 1 Percut Sei Tuan Medan. Pelita Informatika Budu Darma, Volume IX No. 3 ISSN : 230-9425

[3] Kusrini, Emha Taufiq Luthfi, "Algoritma DataMining", 2009.

[3] http://www.pusat-definisi.com/2012 /11 /suami- adalah.html. 